\title{
Commitment to Passenger Safety in Arab Jurisdictions
}

$$
\text { الالتزام بسلامة الركاب في القوانين العربية }
$$

\section{Mohaimen Ismael Kadhum, Al Farabi University College Iraq}

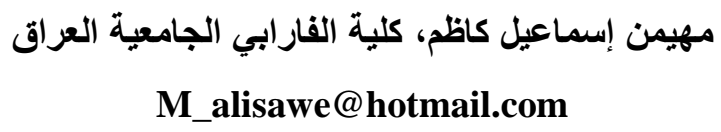

M_alisawe@hotmail.com

\begin{abstract}
Considering the expanding literature on public transportation, which covers topics as diverse as railway disruption management and electric vehicle scheduling, few people are aware of the legal frameworks that support public transportation networks. Nonetheless, such regimes are critical to successful public transportation management because they define the rights and duties of public transportation operators and passengers, with the goal of limiting passenger annoyance and injury while also improving their overall safety. We look at a key component of public transportation, namely the transporter's dedication to passenger safety, as it is practiced in Arab countries like Egypt and Iraq. We do so by drawing on the French legal system, which has impact-ed the development of pertinent legislation in those countries substantially. Our research is qualitative and analytic in nature, and it is based on legislation, textbooks, journals, and official governmental publications. It helps to raise knowledge about the legal implications of public transportation.
\end{abstract} ability.

Keywords: Transport of persons, Contract, Passenger, Safety, Li- 


\section{Mohaimen Ismael Kadhum 28}

الملخص:

بالنظر إلى الدراسات والمؤلفات المتزايدة حول النقل بشكل عام، والتي تغطي مواضيع متنوعة مثل النقل البري والنقل عبر السكك الحديدية، والغريب أن هناك قلة قليلة من الناس على دراية بالأطر القانونية التي تدعم شبكات النقل العام.

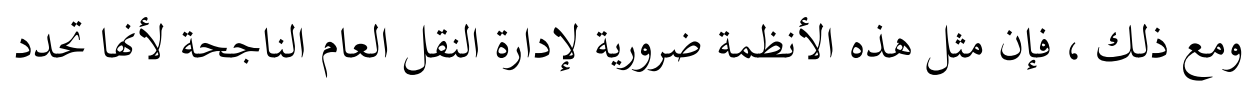

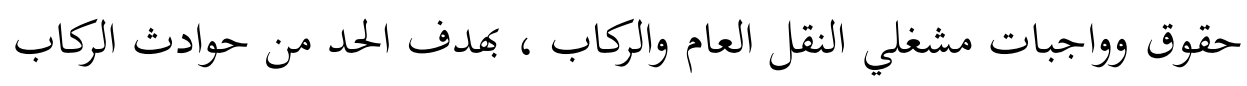

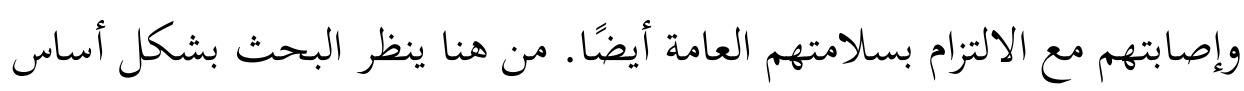

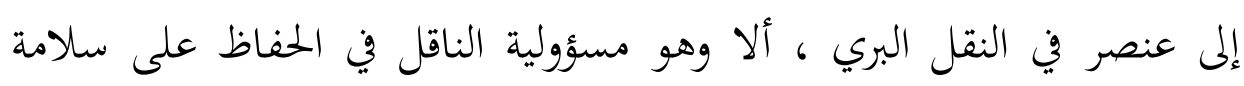

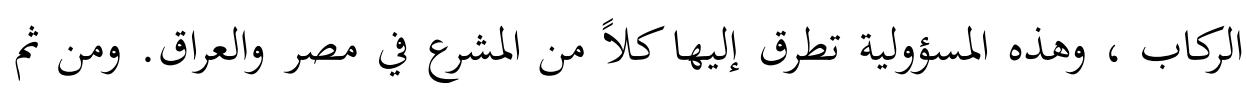

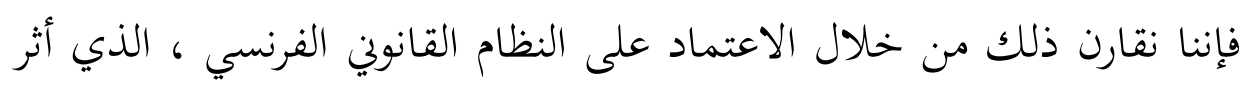

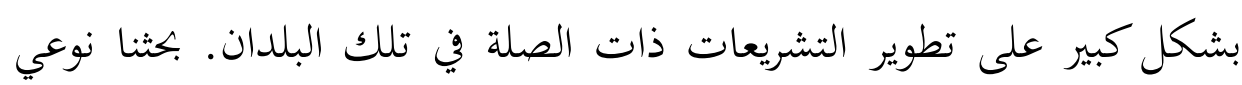
وتحليلي بطبيعته ، ويقوم على التشريعات والمجلات والمنشورات الحكومية الرسمية. يساعد على زيادة المعرفة حول الآثار القانونية للنقل البري. الكلمات الدلالية: انقل الأشخاص ، العقد ، الركاب ، الأمان ، المسؤولية.

\section{Introduction}

The responsibility to safeguard human safety has long been a source of consternation for legal academics who have struggled to find a way to assure the physical safety of human beings. Their goal was to integrate them into the existing civil liability system, even though physical protection was only feasible under that system if it could be proved that the injury 


\section{Commitment to Passenger Safety in Arab Jurisdictions}

complained about was caused directly by a breach of the responsibility to guarantee human safety (Ali Sayyed, 2003). Commitment to human safety has permeated the national consciousness in Arab jurisdictions, and this attitude is progressively pervading major aspects of social life. Importantly, it has permeated all means of transportation, air, land and sea, reminiscent of trends observable in other legal jurisdictions, such as France, Germany, Switzerland and Italy. Hence, transporters of persons are now saddled with an obligation to ensure the physical safety of passengers.

Often, however, the protection of a passenger, who has suffered harm, may ultimately rest on the discretion of an insurer, which may renege on the payment of compensation allegedly because of the passenger's breach of a term in the insurance contract. At the same time, the passenger's body and physical integrity ought, without doubt, to enjoy absolute protection. as Our paper focuses specifically on the meaning of commitment to passenger safety, its legal nature, characteristics, time frame, and general implications. Also examined are prohibitions on transporters of persons from exempting themselves from commitment to passenger safety, and the legal validity of contracts contravening such prohibitions. 


\section{Mohaimen Ismael Kadhum 30}

\section{EVOLUTION OF OBLIGATION TO ENSURE PASSENGER SAFETY}

In a wide range of contracts, the legal term "commitment to safety" has been used. As a result, it has almost completely lost the connotation it had when it was initially employed in transportation contracts to provide appropriate passenger protection. Nonetheless, the concept fundamentally indicates that a person transporter is responsible for a passenger's safety by securely carrying him to his agreed-upon locations. As a consequence, it is essentially a commitment to accomplish a specific goal. Provided, therefore, that the contract is valid in the sense that two key elements are established namely, transportation and consideration, the transporter is obliged to ensure the passenger's safety, irrespective of the means of transportation used in executing the contract, be it a car, bus, train or tram (Wajdi, 2004). For this reason, commitment to safety attracts significant legal importance, as manifested by judicial and scholarly opinions that have trailed the evolution of transportation vehicles and their associated risks, especially in countries that lacked rules governing contracts for the transport of persons (AL-Meqdaady, 1997).

Obligation to ensure safety first emerged in Czarist Russia in 1838, following the adoption of a railroad bill. This was in response to a ruling by the Russian Court of Cassation to the effect that the transport of persons entails an obligation on the part of transporters to deliver passengers safely at their agreed destinations. This, according to that Court, is an obligation to achieve a result and if a passenger were to suffer any harm, it would be sufficient to render the transporter liable by proving that the harm occurred in the course of transportation. Exemption from liability is only possible if 


\section{Commitment to Passenger Safety in Arab Jurisdictions}

the transporter is able to prove that the harm suffered by the passenger arose from force majeure, the passenger's fault or the fault of a third party, which the transporter could not reasonably have anticipated. The notion of obligation to ensure passenger safety subsequently spread to other jurisdictions. Germany, for example, adopted a law on commitment to safety in April 1881, largely aided by the Reich court verdicts. Belgium followed suit in August 1891 and Luxembourg in February, 1908 (Tharwat, 1995).

In France, commitment to safety was initially concerned with workplace safety. It arose from mounting pressure on the French judiciary to apply the rules of contractual liability, which was predicated on employment contracts by virtue of which employers were committed to the safety of their employees at workplaces. The initial reluctance of the French judiciary to do so, led to legislative intervention by way of a law issued on 9 April 1898, which sought, through a special provision, to enforce employers' commitment to the safety of their employees (Mustafa, 1971).

All that said, in the field of transportation, commitment to safety can, strictly speaking, be traced to the French judiciary because of its role in providing the most extensive and influential jurisprudence on this subject. Ironically, French legislators failed initially to make legal provisions regulating contracts for the transport of persons. Rapid expansion in the modes of transportation and the vastly increased risks that accompanied them would later render the situation more untenable. Unlike the legislature, the French judiciary recognised this problem and took the initiative, through court verdicts or views expressed in commentaries to court verdicts, to clarify the type of responsibility borne by transporters of persons (Sherif, 2005). 


\section{Mohaimen Ismael Kadhum 32}

Their goal was to ensure the safety of passengers, who had grown considerably more vulnerable to mishaps while traveling, some of which were fatal. As a result, they established the idea of passenger safety as a legal responsibility. However, the situation was complicated by the fact that the French judiciary had already expressed reservations about the subject. The French Court of Cassation, for example, declined to apply Article 1784 of the French Civil Code to the transit of individuals on November 10, 1884.That article was applied exclusively to the transport of goods on the rationale that principles governing transporters of goods could not be applied to transporters of persons. While goods are static, enabling transporters to exercise total control over them, in contracts for the transport of persons, passengers enjoy freedom of movement, making it more challenging for transporters to ensure their safety (Wajdi, 2004). The much desired change finally came on 21 November 1911, when the French Court of Cassation ruled that a transporter is responsible for the safety of its passengers and liable for any harm suffered by them in the course of transportation. This was reaffirmed in another ruling on 27 January 1913, which stated that "the railway company is obliged to deliver passengers sound and safe." (Abdel, 1954).

This commitment imposes an obligation on the transporter to achieve a specific result, which is the safe delivery of passengers at their destinations. A transporter is not entitled to exemption from this obligation, unless it can prove the occurrence of an external event that severs the link between its fault and the harm suffered by a passenger during the performance of the transportation contract. Thus, it was the French courts that originally conceived the obligation to ensure safety concept in its true 


\section{Commitment to Passenger Safety in Arab Jurisdictions}

sense (Mohammed Ali, 1980). It would seem though that the Egyptian judiciary were already ahead of their French counterpart in the above regard. As far back as 23 December 1886, they had ordered transporters to assume the obligation to ensure the safety of passengers by taking them to their destinations safe and sound (Judgment of the Court of Appeal [Mixed Courts], December 23, 1886). However, the Egyptian courts did not formalise their jurisprudence on the transporter's commitment to passenger safety until the ruling of the Criminal Court of Cassation of 18 December 1941, which was later supported by the ruling of the Court of Civil Cassation of 26 April 1962 (Ibrahim, 1980).

Altogether, it can be seen that social and humanitarian considerations influenced the emergence of rules imposing an obligation on transporters to ensure the safety of their passengers and safeguard them from bodily harm. Given the central importance of the passenger's physical integrity, transporters are legally barred from claiming exemption from this obligation or seeking to narrow its scope. The obligation is, however, not uniform, and varies with the particular means of transportation in question; land, air or sea (Ibrahim, 1980).

\section{The Transporter's Commitment to Passenger Safety: Contractual or No contractual?}

One of the primary influences on the formation of the idea of civil responsibility was the movement of people. Contractual and non-contractual responsibility are two aspects of this notion. According to the rules, the transporter's obligation for passenger safety alternates between these two types of liability. In certain situations, such responsibility will be assessed 


\section{Mohaimen Ismael Kadhum 34}

using contractual liability principles, while in others, non-contractual liability rules will be used. Under French jurisprudence, civil liability may be based on either tort law or contract law.

This is an emanation of the principle of non-cumuli des responsibilities (French Civil Code, Article 1927). It means that contractual liability is separate from tortious liability, even though both are complementary. Contractual liability arises from the breach of contractual obligations, while tortious liability is the penalty for the nonobservance of the rules governing conduct as prescribed by statute, regulation or case law. In France, other than cases of liability arising from breach of contractual obligations, (Viney G, Van Gerven W, Lever J, Larouche P, 2000) the general rules of tortious liability applied pursuant to Article 1382 of the French Civil Code. As provided in that article, "any act of man, which causes damage to another, shall oblige the person by whose fault it occurred to repair it." Moreover, according to Article 1383 of that Code, "one shall be liable not only by reason of one's acts, but also by reason of one's imprudence or negligence."

It is clear from the phraseology of Article 1382 that three requirements must be met to establish liability namely, fault, damage and the existence of a nexus between that fault and the damage. The onus is on the party making a claim to fulfil these requirements. In the context of Article 1383, a fault may be the commission of a prohibited act or the omission to perform an otherwise required act. It may be defined as wrongful conduct judged against the standard of a reasonable man; a failure to behave as a bonus pater familias or a bon pere de famille (Karel, 2013). In other words, in the case of a commission, a reasonable man, placed in the position of 


\section{Commitment to Passenger Safety in Arab Jurisdictions}

the wrongdoer, would have refrained from the act in question, while with regard to omission, he would have performed the act, which the wrongdoer omitted to perform.

Another point worth noting is that, under French law, to commit a tort, a party need not be aware of the wrongfulness of his action, neither does he need to owe the injured party any specific duty of care. To be able to claim damages for harm suffered, all that is required of the claimant is proof of a fault and damage, as well as a causal link between the two. Fault is, by and large, a subjective concept, giving the courts considerable latitude in the attachment of liability, based on the particular circumstances of each case. The provisions of Articles 1382 and 1383 of the French Civil Code have widely been construed as not exclusively delineating the scope of protected rights and interests. The exact scope of the protection offered by tort law has, nonetheless, been underexplored in French jurisprudence. Indeed, from the standpoint of French law, it would be misconceived to talk of "protected rights" in an exclusionary sense (Viney G, Van Gerven W, Lever J, Larouche P, 2000). Those provisions have a general application and cover all forms of acts causing harm.

Clearly though, until the early 20th century, in the resolution of disputes between transporters and passengers over harm suffered during transportation, French courts only applied the no contractual liability rule. Despite the contractual nature of the underlying transaction from which it arose, they treated the passenger's harm as a non-contractual one, following Article 1382 of the French Civil Code. To successfully claim compensation under that article, the burden lay on the passenger to prove fault on the transporter's part and to establish a causal connection between that fault 


\section{Mohaimen Ismael Kadhum 36}

and the harm suffered. That requirement proved too burdensome for passengers to fulfil. The rising numbers of accidents suffered by passengers in the course of transportation and the inability of the no contractual liability rule to afford them the desired remedy made the situation increasingly intolerable. The following subsection explains how the no contractual liability rule eventually gave way to the emergence and eventual dominance of the contractual liability rule.

\section{Rise and Dominance of the Contractual Liability Rule in the Adjudication of Accident Disputes}

As previously stated, the concept of protected rights is based on the occurrence of harm, which is one of three requirements for compensating entitlement. Yet, whether in legal research or in the case law of the French Court of Cassation, the concept of harm has received little attention.

The law simply specifies the characteristics that an alleged harm must possess in order to be compensated: it must exist, be definite, and be directly connected to the claimant. To provide greater protection for claimants, the case law has, in subsequent decades, developed a specific type of damage known as perte d'une chance, meaning loss of an opportunity. This is invoked in cases where the damage involves the victim's loss of opportunity to obtain an advantage or avoid a loss. To satisfy the requirements of certainty and directness, that opportunity must be reelle et serieuse, which means real, serious and not speculative (Abdulqaader, 2010).

Further, although liability attaches to a fault only if there exists a direct causal relationship between that fault and an alleged damage, neither statute nor case law provides guidance on what exactly may constitute such a relationship. This gives the courts a great deal of discretion on the matter. 


\section{Commitment to Passenger Safety in Arab Jurisdictions}

Regardless, it should be remembered that causation is usually construed in the context of two conditions concerning damage namely, certainty and directness. As to the requirement of certainty, this has long been recognised by the French Court of Cassation. The requirement of directness, itself, is derived from Article 1151 of the French Civil Code, which states that "damages extend only to the direct and immediate consequences of the breach of contract." While this provision ostensibly deals with liability for breach of contract, it is widely seen as expressing a general principle equally applicable to tort law.

Therefore, once the three conditions of fault, damage and causal relationship are met, a claimant is entitled to compensation for a wide variety of injuries, including material and pecuniary injuries, bodily injuries, as well as moral injuries, such as pain, suffering and loss of enjoyment. In essence, French law is underpinned by the principle of reparation integrale, which means full compensation. The idea is to ensure that, as much as possible, compensation equals the harm, even though achieving this aim is often problematic, especially in situations involving nonmaterial harm (Georges Ripert, René Roblot, 1996). Full compensation covers material injury to the bodily integrity of the claimant, his property and general estate, as well as material loss, such as loss of financial support, and nonmaterial injury, including, for example, pain and suffering by persons suffering from the death or injury to the physical wellbeing of the claimant1. Nonetheless, as

1 In that connection, it should be noted that in recent times, some doubts have been voiced by legal writers as to whether the principle of full compensation should be as literally and consistently applied as it is by the French courts, particularly with regard to non-material damage. They also 


\section{Mohaimen Ismael Kadhum 38}

observed earlier, French courts previously viewed the transporter's liability as no contractual rather than contractual. They applied the rules of tortious liability, based on Article 1382 of the French Civil Code, which required passengers to prove the transporter's fault as a condition for the payment of compensation.

Nevertheless, that article pertained to all sorts of activities that cause injury, and the accompanying duty for safety was limited to the transportation of products, not people. The courts attempted to impose numerous criteria on carriers to reduce the burden on passengers, the most notable of which was:

i. As a preventive step to protect passenger safety, railway firms were required to adopt a variety of legal obligations.

ii. Emphasized transporters' duty in a variety of scenarios, such as when a train derails or collides with another.

Those precautionary measures were assessed by a trial judge, who could determine the liability of the transporter in relevant cases. Still, application of the tortious liability rule provided in Article 1382 of the French Civil Code proved too onerous for passengers, who, as accident victims, were required to establish the transporter's fault, for example, in the form of an installation error or lack of maintenance. Those are technical matters about

point out the difficulties the courts are experiencing in translating non-material harm into money. 


\section{Commitment to Passenger Safety in Arab Jurisdictions}

which passengers are barely knowledgeable. Even where a passenger managed to prove fault, the transporter could still escape liability by showing that it made frantic effort to exercise due care, thereby disproving the claim that the passenger's injury was the result of its own fault. In response to the need for change, some French jurists proposed that commitment to safety should be included in transportation contracts with a view to availing accident victims of the right to compensation outside the ambit of $\mathrm{Ar}$ ticle 1382 of the French Civil Code. This would render the transporter liable to pay compensation to the passenger based on the contractual liability rule whenever that commitment was violated. In retrospect, it would seem that Article 1784 of the French Civil Code, which was thought to apply exclusively to the transport of goods and to oblige transporters to ensure their safety was, after all, an application of this general principle of contractual liability. Perhaps, that partly explains why French legislators considered it unnecessary to include a similar provision for the transport of persons (Mohammed Wahid, 2001).

If a transporter commits to the safety of goods owned by its passengers, then it arguably commits even more to the safety of those passengers and to deliver them safely at their agreed destinations. Put differently, the transporter commits to the safety of its passengers, even before assuring the safety of their goods. Among such contacts, is the transportation contract, which imposes a responsibility on the transporter to carry passengers safely to their agreed destinations, even when this is not expressly declared. Thus, according to Article 148 of the Egyptian Civil Act, "the contract does not merely make it compulsory for a party to observe the content of the contract, but also its requirements according to law and justice based 


\section{Mohaimen Ismael Kadhum 40}

on the type of commitment." A French court took that same line, when it ruled that a transporter of persons necessarily commits to their safety, as it is inconceivable that passengers would contract with a transporter that commits only to the safety of their goods, while refusing to commit to their own physical safety (Abdulqaader, 2010).

What proved to be a historic moment finally arrived when, as mentioned already, the French Court of Cassation issued a ruling on 21 November 1911, endorsing the extension of the contractual liability rule to transporters of persons. In the dispute leading to that ruling, a passenger, who was travelling from Tunisia to Germany, aboard a ship operated by the General Corporation for Navigation Across the Pacific Ocean, was seriously injured due to poorly positioned storage on the ship. When the matter came before the French Court of Cassation, it ruled that the contract concluded between the transporter and the passenger formed the basis for the determination of the transporter's liability, rather than the no contractual liability rule. The Court then added the now trite judicial principle that "performing a transportation contract requires the transporter to commit to carrying the traveller safely to his destination." (Abdulqaader, 2010). The French Court of Cassation issued another equally instructive ruling on 27 November 1913, in a case relating specifically to the transport of persons by land. It expressed the view that "handing the ticket to the traveller by itself and without explicitly making a condition, includes the commitment of the railway company to carry the traveller safely to his destination." (Mohammed Wahid, 2001).

The injury suffered by the passenger was proof that the transporter had breached its commitment. Thus, its liability was no longer no contractual, 


\section{Commitment to Passenger Safety in Arab Jurisdictions}

but contractual. It, therefore, came within the scope of the objective, which the commitment to safety principle was meant to serve. The Court emphasised that a transporter has a specific obligation to attain a certain result, which is to transport passengers safely to their destinations (Hasan , 2006). In yet another important ruling, the French Court of Cassation reiterated that when a passenger obtains a travel ticket, a commitment to safety is imposed on the transporter, implying that it is incumbent on the transporter to transport that passenger safely to his destination (Majid, 1984).

That ruling was issued in clear and unambiguous terms and a transporter cannot circumvent this commitment, unless it is able to show that the harm suffered by the passenger was caused by an extraneous factor, rather than its own fault. Thus, in addition to formally affirming and extending the commitment to safety principle to the transport of persons, the rulings of the French Court of Cassation also marked a shift from the no contractual to the contractual liability rule for the resolution of accident disputes between transporters and passengers. The goal of the commitment to safety principle, therefore, was to relieve accident victims of the daunting task of proving the transporter's fault (Lambert-Faivre, 1993). Under the contractual liability rule, all that is required from an aggrieved passenger seeking compensation, is proof of harm and the existence of a valid transportation contract with the transporter. It should be made clear that, in all cases, and irrespective of the means of transportation involved, the contractual liability of the transporter commences right from the time when the passenger's body comes into contact with the transportation vehicle. This liability continues throughout the life of the contract and terminates only when the passenger arrives safely at thin tended destination (Mohsen, 1955). 


\section{Mohaimen Ismael Kadhum 42}

\section{THE LEGAL NATURE OF THE OBLIGATION TO ENSURE PASSENGER SAFETY}

A carrier is responsible for securely transporting passengers to their agreed-upon locations. In extreme situations, a physician may commit to ensuring a patient's safety when he commits to attaining a certain result, much as a hotel owner may commit to ensuring the safety of visitors. The vexing question in all of these situations is what the real nature of that commitment is. Is the obligation in the instance of the transporter just to convey the passenger from the place of departure to an agreed-upon destination or to transport him safely to that destination? An obligation to achieve a result is one whose primary purpose, as the word indicates, is to accomplish a certain goal. An example of this obligation is a seller, who sells his goods to a buyer and undertakes to deliver them at a specified time. Once that result is achieved, the buyer has to fulfil his own commitment, which is to pay the agreed price for the goods delivered. Similarly, in transportation contracts, the transporter commits to transporting the passenger to an agreed destination and does not complete the fulfilment of this commitment until the result is achieved, which is the safe delivery of the passenger at that destination.

Unlike the commitment to achieve a result, the commitment to provide guarding relates to those measures that a transporter adopts in the interest of the passenger to prevent his exposure to any form of risk. In this case, though, the transporter has no obligation to achieve a result, meaning to transport the passenger safely to the agreed destination. Rather, its commitment is restricted to offering the required guarding by taking all steps necessary to provide conditions conducive to the passenger (Hasan, 2006). 


\section{Commitment to Passenger Safety in Arab Jurisdictions}

Therefore, the judiciary attempts to extract the commitment to passenger safety right from the beginning, because this commitment is almost always an obligation to attain a result. Consequently, a transporter is liable for any harm caused to a passenger, without the latter having to prove the former's fault. The transporter's obligation is not extinguished, unless it can prove that the passenger's injury was caused by an external factor.

As a further and more specific illustration, if a passenger boards a taxi for a specified destination and in the course of transportation, an accident occurs or an external factor causes a delay or an injury to the passenger's physical being, the question here would be whether the transporter has an obligation to achieve a result or to offer proper guarding. That is why both forms of obligation must be differentiated. In the early 20th century, the French courts started to differentiate between the obligation to achieve a result and the obligation to provide proper guarding. French jurists and legal scholars believe that commitment to safety may either be to achieve a result or to offer guarding. Since a transporter commits to a passenger's safety, meaning an undertaking to transport him safely to his destination, he thereby commits to achieving a result, rather than offering proper guarding. The transporter cannot rid itself of this obligation, unless it is able to prove that an external factor caused the harm suffered by the passenger (Mohammed Ali, 1980).

It should be noted that in transportation contracts, the transporter does not only undertake to adopt measures for assuring the safety of passengers and goods, but also for delivering them at their destinations safely. Establishing the transporter's obligation is based on contractual fundamentals. It is based on a contract whereby the transporter agrees not merely to transport 


\section{Mohaimen Ismael Kadhum 44}

the passenger and his goods, but to do so safely, even without any express safety assurance terms. The passenger also should not accept a transportation contract that does not impose this obligation on the transporter. The contract for the transport of persons establishes the transporter's commitment to safety. The transporter would be liable if a passenger is harmed during the execution of the transportation contract. Such liability would be based on the contractual liability rule (Samir, 2005) and the transporter would be liable to pay compensation, unless it is proven that the passenger's injury resulted from a foreign cause, the passenger's fault or the fault of a third party (Abdul Hamid, 1992). The commitment to passenger safety lasts throughout the duration of the transportation contract. It begins with the execution of the contract and terminates with the achievement of the intended objective, which is the safe delivery of the passenger at the agreed destination.

The commitment to safety is not linked to the purchase of a travel ticket, which may be done subsequent to the commencement of the contract or close to the end of its execution. The commitment cannot be deferred until the transportation commences or terminated before it ends. Sometimes, a passenger may purchase a ticket long before the date of the planned journey. During this period, no relation exists between the passenger and the transporter. However, the transporter's liability exists, although it becomes effective only upon the commencement of the original commitment to transport the passenger. 2

2 However, when fare payment is required in advance, such as in rail transport, passengers must obtain the ticket in advance, and the contractual safety obligation begins since the ticket is handed out to the conductor or 


\section{Commitment to Passenger Safety in Arab Jurisdictions}

Therefore, the transporter cannot rely on the excuse that an accident occurred before the passenger handed out his travel ticket. This is because the passenger's acceptance of the transporter's offer of transportation takes place the moment he sets foot on the transportation vehicle. By this act, the passenger demonstrates his acceptance of the transporter's commitment to safety, which begins when the passenger boards the train and ends with his exit at the agreed destination.

\section{Conclusion:}

Passengers have been better protected as a result of commitment to safety in transportation contracts. Although it initially appeared in Czarist Russia in the fourth decade of the nineteenth century, the French courts did not properly and thoroughly explain the notion until the early twentieth century. This was a response to an increase in the number of accidents and the lack of efficient cures for passengers who had been injured while traveling. The notion has now extended to a number of Arab countries. the law has provided the maximum possible protection for passengers.

commitment to safety is not merely an obligation to provide proper custody, but a contractual obligation to achieve a certain result. This is the transport of a passenger to his intended destination safely. Failure to

the machine existing at the beginning of the terminal, and ends at the arrival station. A breach of the safety obligation is caused if a passenger is injured after entering the platform and before leaving the station. In the means of transportation in which the fare is paid during or after arrival, such as a taxi, the carriage contract shall take place at the moment the passenger gets in the means of transport, because the commencement of this entry means acceptance of the permanent offer by the carrier. 


\section{Mohaimen Ismael Kadhum 46}

achieve this result would render the transporter liable to pay compensation on the basis of the contractual liability rule, unless it proves the intervention of an external superior cause. In light of the analysis of the legal nature of commitment to safety, its time frame and key characteristics, this paper concludes by proffering a definition for commitment to safety in transportation contracts. For some legal scholars, "safety is the control by the transporter over persons and items that may suffer physical harm, and executing such control completely requires a preemptive step in terms of anticipating any dangers that may befall such persons and items, and then deciding what should be done about them either by preventing or minimizing them" Although the above definition identifies some of the elements of commitment to safety, it is too general and not specific to transportation. It also fails to identify the form of this commitment and related implications. More appropriately defined, the concept of safety may be said to mean that the transporter exercises actual control over all the possible elements that may cause harm to a passenger. These elements must be included within the framework of the contract that links both contracting parties. Further, the transporter should execute its commitment in line with the standards of its profession. Overall then, it can be concluded that commitment to safety is:

a transporter's commitment, the essence of which is the transport of a passenger by its means of transportation to an agreed destination safely. It starts from the moment the passenger enters the station and lasts until he arrives at the agreed destination. It is an obligation to achieve a result; the assumed control of the transporter 


\section{Commitment to Passenger Safety in Arab Jurisdictions}

over the passenger based on the experience gained from the performance of its professional duty, as well as its experience in anticipating danger and preempting it. If this result is not achieved, the transporter's liability is established, unless it proves that the failure was due to an external cause.

\section{References}

Abu Al-Layl, Ibrahim Al-Dassuqi, 1980, Liability of the Carrier of Persons in Domestic Law and International Law. Egypt: Arab Renaissance House.

Al-Anbakee, Majid Hamid, 1984, Iraqi Transport Law (Principles and Provisions). Iraq: Publications of the Legal Research Center.

Al-Asyoti, Tharwat Anis, 1959, Liability of air carriers in comparative law. Ph.D thesis Cairo Law College.

Ali, Wajdi Abdul Wahid, 2004, Compensation for Breach of the Obligation to Ensure the Safety of Passengers and Travellers. Egypt: Egyptian Books House.

AL-Meqdaady, Adel Ali, 1997, Liability of land Transporter in the Transfer of Persons (Comparative Study), Jordan: Culture House Bookshop for Publication and Distribution.

Al-Sadah, Abdel Moneim Farag, 1954, Obligation resources. Egypt : Arabic Renaissance House.

AL-Shawarbi, Abdul Hamid, 1992, Commercial Act: Commercial Contracts. Facility Knowledge. Egypt: Publishing House.

Al-Tabbaakh, Sherif Ahmed, 2005, Compensation for land, sea and air transport in light of justice (jurisprudence and international treaties). Egypt: University Thought House. 


\section{Mohaimen Ismael Kadhum 48}

Aqsaasi, Abdulqaader, 2010, Commitment to safety in contracts: towards a general theory. Egypt: University Thought House.

Danoun, Samir Suhail, 2005, Civil Liability for Mechanical Machinery and Compulsory Insurance (Comparative Study). Lebanon: Modern Book Foundation.

Georges Ripert, René Roblot In: Philippe Delebecque, Michel Germain, (eds.), 1996, Commercial law treaty. vol. 2. commercial paper bank. commercial contracts. collective proceedings. 15th ed. General Library of Law and Jurisprudence (LGDJ). Paris. Tome 2. 17 Edition,

Imraan, Mohammed Ali, 1980, Commitment to safety and its application in some contracts, juristic and judicial study in Egypt and France. Egypt: Arab Renaissance House.

Jamai, Hasan Abdul Baaset, 2006, The extent of the assumption of professional error in the division of obligations into obligation to achieve a result and obligation to care. Fact book Professional Responsibility Conference. Faculty of Law. University of Sharjah, UAE, 3-5 April, 2004. University of Sharjah: Center for Research and Studies.

Lambert-Faivre, 1993, The Law of Corporal Damage, 2nd edition, Dalloz : Paris.

Mohammed, Wahid Mohammed, 2001, Commitment to safety in contracts. Egypt: Arab Renaissance House.

Qaasim, Ali Sayyed, 2003, Business law. Egypt: Arab Renaissance House.

Roynette, Karel, 2013, Drawing the line of the scope of the duty of care in American negligence and French fault-based tort liability.

Sahfeeq, Mohsen, 1955, The Mediator in commercial law. 2nd Ed. part 2. Egypt: Union University Press. 


\section{Commitment to Passenger Safety in Arab Jurisdictions}

Taha, Mustafa Kamal, 1971, Commercial Act. Egypt: Modern Egyptian Office.

Viney G, Van Gerven W, Lever J, Larouche P, 2000, Cases, materials and text on national, supranational and international tort law. Oxford: Hart Publishing. 